\title{
Mapping the Tobacco Retailers in Edirne, Turkey
}

\author{
Celal Karlıkaya ${ }^{1}$, Hüseyin İnce², Nurcan Özkan³ \\ ${ }^{1}$ Department of Chest Diseases, Faculty of Medicine, Trakya University, Edirne, Turkey \\ ${ }^{2}$ Department of Architecture and City Planning, Technical Sciences Vocational School of Trakya University, Edirne, Turkey \\ ${ }^{3}$ Department of Primary Education, Faculty of Education, Trakya University, Edirne, Turkey
}

\begin{abstract}
Objective: The youth smoking rate is on the rise in Turkey. Although many marketing bans have been effectively implemented, regulations related to retail tobacco outlets have gone unnoticed and have not been effectively supervised. In this study, we aimed to show the lack of legal regulation related to the high retail tobacco outlet density with displays.
\end{abstract}

Material and Methods: In the center of Edirne, the marketing environment, numbers and geographical distribution of retail tobacco outlets were documented and mapped with geographical positions.

Results: There were 569 retail tobacco points of sale in 520 stores. We calculated one tobacco retail outlet per 270 people. This retail outlet density rate is above the national average and about four times higher than the density in Istanbul. Products especially attracting children, such as chocolate, sweet candy and chewing gum, were set up near the tobacco stands and were easy for children to recognize and reach. It can be seen on the city map that $47 \%$ of retail tobacco outlets are within $100 \mathrm{~m}$ of education, health or sport facilities.

Conclusion: We concluded that one of the reasons for the increasing prevalence of cigarette use, especially among adolescents in Turkey, is deregulation of the retail tobacco marketing industry as a result of the privatization process of the national tobacco monopoly. Using mapping techniques can be useful in terms of controlling the retail marketing environment.

Key Words: Tobacco retail, advertising and promotion, public policy, denormalization, environment, globalization

Received: 28.10.2011

Accepted: 12.03.2012

\section{Introduction}

Every year in Turkey, approximately 100,000 people die due to diseases related to tobacco use. In spite of this fact, $31.2 \%$ of people aged 15 years or older, or roughly 16 million people, smoke tobacco (1). Although adult use has declined in recent years, the incidence of tobacco use among teenagers and children is on the rise. According to the results of the Global Youth Tobacco Survey, $8.4 \%$ of students ( $10.2 \%$ of boys and $5.3 \%$ of girls) smoked cigarettes in Turkey in 2009. However, according to the results of the same study in 2003, the percentage was $6.9 \%$ (9.4\% of boys and $3.5 \%$ of girls) (1). The increase in the smoking rate in girls is evident.

One of the main reasons for the epidemic of tobacco use is tobacco industry activities in terms of advertisement, promotion and sponsorships. According to the Turkish Tobacco Control Law, 4207, direct or hidden tobacco ads have been forbidden since 1996. Additionally, Turkey ratified the Framework Convention on Tobacco Control (FCTC) Treaty in 2004, which states that advertisement, promotion and sponsorship bans of tobacco are among the major measures according to the FCTC. Although many bans of advertisements, promotions and sponsorships are effectively put into practice, regulations related to retail tobacco outlets have gone unnoticed and have not been effectively supervised. In fact, it has become deregulated in many ways. Point-of-sale advertising arouses interest in consumers and potential consumers and is known to play an important role for tobacco companies, especially in countries where the tobacco advertisement bans are effective (2). It has been proven that tobacco point-ofsale tactics influences smoking initiation by youth, prevents smoking cessation and increases the return to smoking by exsmokers; therefore, it is warranted to regulate point-of-sale practices $(3,4)$. The current Turkish legislation stipulates that "the sale of tobacco products is strictly forbidden in places where services for health, education, culture and sport are provided" (5), but we believe that this is not enough to protect public health.

The use of cadastral mapping, or geographic information systems, provides substantial benefits in surveillance, planning and monitoring problems and/or facilities related to community health and displaying and analysis of data $(6,7)$. The Tobacco Atlas ${ }^{1}$, the foremost source on the topic of tobacco, considers mapping as one of the most powerful weapons for tobacco control.

Our aim in the present study was to document the retail tobacco market practices in terms of point-of-sale ad- 
vertising, numbers and distribution of licensed retail tobacco outlets with geographical position in relation to educational, health and sport facilities.

\section{Material and Methods}

Data were primarily acquired from two sources: i) all of the city streets were visited and retail tobacco outlets and their marketing tactics were documented and ii) licensed retail tobacco stores were visited and positioned geographically, mapped and analyzed on maps.

\section{Visiting and documenting tobacco retailers}

Three separate teams, each of them composed of at least two university students, searched for retail tobacco stores on foot, riding a bicycle or driving an automobile according to road distance, between April and June in 2009. The teams documented the name of the location, its connection with health, education and sport facilities and the characteristics the sale displays. Observers were asked to note the names and addresses of retail cigarette outlets, the primary purpose of the service (supermarket, petrol station, restaurant, etc.), the characteristics of the sale booths such as whether children could access the location easily, whether they had illuminated advertising, if they observed the sale of cigarettes to children under the age of 18, whether they had employees under the age of 18 and whether they observed the sale of cigarettes one by one or illegal cigarettes without banderoles. Each store was visited only once.

\section{Mapping and determining geodetic positions of retail tobacco outlets}

The list of canteens, shops, supermarkets, nightclubs, gas stations, etc. licensed for selling retail tobacco products was provided by the Edirne Chamber of Commerce between January and June in 2010. Licensed retail stores on the list were visited by experts on mapping. The exact locations of the stores were recorded by determining the approximate geodetic position with a Magellan GPS device, a high-sensitivity receiver with a sensitivity of $\pm 5-10 \mathrm{~m}$. Coordinates acquired with GPS were transformed to the national coordinate system. A map of 1/1000 scale showing the entire parcel numbers and house numbers that constituted the municipality of Edirne was digitally transformed with Netcad ${ }^{\mathrm{TM}}$ software. All retail tobacco stores, health institutions and organizations (private and state hospitals, community health centers), educational institutions and sport facilities were mapped according to their GPS locations. Special marks were used on the map: educational institutions were marked in pink, health institutions in green, sport facilities in blue, retail tobacco outlets as two black circles, one within the other, while large stores with multiple points of sale had multiple circles within each other and retail tobacco outlets without a license were red with multiple circles within each other. Education, health and sport facilities, which should have been $100 \mathrm{~m}$ away from retail stores according to previous legislation that expired after the privatization of the National Tobacco Monopoly, were mapped as exclusion zones.

\section{Results}

\section{Empirical and qualitative findings}

It was found that retail tobacco stores included canteens, shops, supermarkets, shopping centers, sellers of dried nuts and fruits, restaurants, cafes, night clubs, cafeterias, charcuteries and gas stations. Photographic documentation was limited as sellers were opposed to having photographs taken. It was found out seven 7 retailers were out of the city center limits, 10 retail outlets were closed and 520 retail tobacco outlets were active out of 537 licensed outlets. The total number of retail points was 569 including shopping centers. No retailers were found without a license. Three licensed retailers had only illuminated advertising displays without selling tobacco. It was found that sales stands (booths) were mostly illuminated, charming and as interesting as if they had illuminated advertising even at small selling points. The sales stands were easy for children to reach and there were attractive products for children such as chocolate, sweet candy and chewing gum near tobacco stands (Figure 1). Observers witnessed the sale of cigarettes to children under the age of 18 in almost half of the retail stores, despite making only one visit. The observers also noted employees under the age of 18 at two of the retail outlets. They did not witness the individual sale of cigarettes one-by-one nor did they find any smuggled cigarettes during the site visits. However, it was noted that in a few situations, people witnessed the sale of cigarettes one-by-one, especially at selling points around schools. The tobacco sales stand of a retailer was out of view and the seller indicated that he did it consciously so as not to promote the sale of cigarettes. According to the remarks of observers, almost $41 \%$ of selling points were $100 \mathrm{~m}$ or closer to education, health or sport facilities.

\section{Geodetic positioning of tobacco retailers}

According to the retailer list from the city authority, there were 520 retail tobacco outlets currently active. Shopping centers had only one license, but had multiple sales stands and point of displays. When sale stands were counted individ-

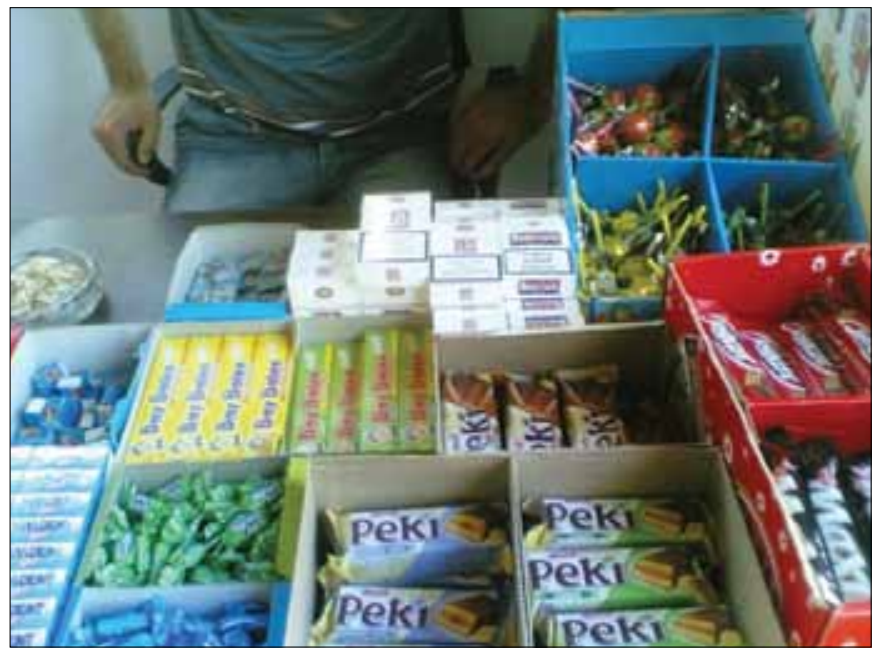

Figure 1. An example of a tobacco "powerwall" set up with goods for children such as chocolate, candy, chewing gum, etc 
ually, the total number of retail tobacco point was 569 . They are shown as black points on the map (Figure 2). The density of retail tobacco outlets was much greater in the city center than any other place. According to the map, almost half of the outlets were within the $100 \mathrm{~m}$ exclusion zone. Retail tobacco stores within the $100 \mathrm{~m}$ zone were counted and the results were shown in Table 1. It was found out that $47 \%$ (268 out of 569) of the retailers were within $100 \mathrm{~m}$ of education, health or sport facilities. Of these, $69 \%$ tobacco retailers were close to education facilities, $25 \%$ of them were close to health facilities and $6 \%$ of them were close to sport facilities out of 268 selling points within the $100 \mathrm{~m}$ zone.

\section{Discussion}

Most importantly, this study documented that $47 \%$ of retail tobacco outlets are within $100 \mathrm{~m}$ of education, health or sport facilities in Edirne. In other words, the licenses of $47 \%$ of selling points should be cancelled according to the legislation that existed before retail tobacco market deregulation occurred in Turkey. Almost all of the tobacco stands were arranged at or near the entry of the store as the most visible consumer products that could be defined as a direct advertisement to consumers and non-consumers, including children. As observational evidence, legislation for selling to children under the age of 18 has not been working in Turkey. It was evident that about half of the outlets were inappropriately licensed and that mapping or geographical information systems could permit appropriate licensing. Moreover, map-

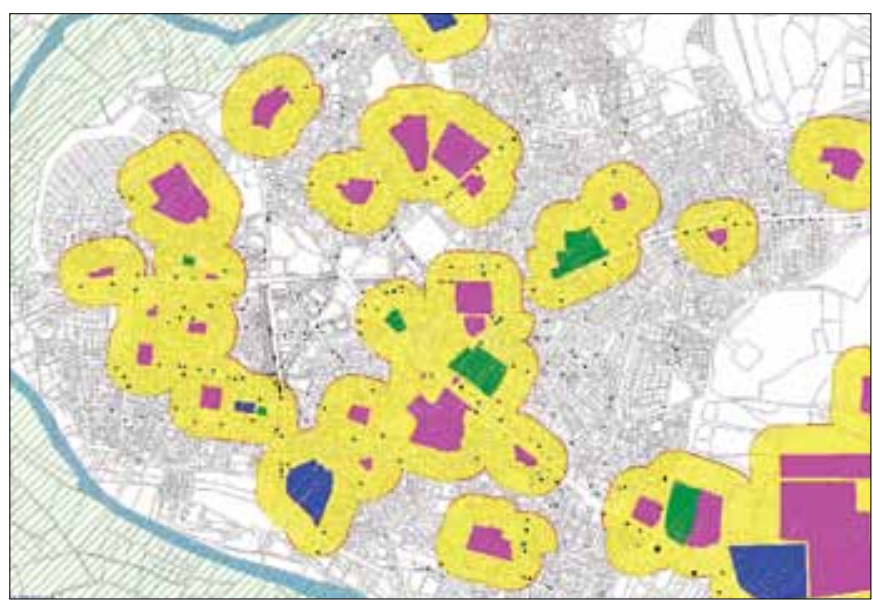

Figure 2. Geodetic distribution of retail tobacco outlets within $100 \mathrm{~m}$ to education, health or sport institutions. Pink zone: education, green zone: health, blue zone: sport intuitions

Table 1. Retail tobacco outlets within $100 \mathrm{~m}$ of education, health and/or sport institutions

\begin{tabular}{|lccc|}
\hline Institutions & $\mathrm{n} / \mathrm{N}$ & $\%$ & $\%$ of tobacco retailers \\
\hline Education & $185 / 268$ & 69.03 & 32.51 \\
Health & $66 / 268$ & 24.63 & 11.60 \\
Sport & $17 / 268$ & 6.34 & 2.99 \\
Total & $268 / 569$ & 100 & 47.10 \\
\hline
\end{tabular}

ping can also provide important clues for further measures like youth prevention projects. As far as we know, this study was the first of its kind in which retail tobacco stores were mapped in Turkey.

Enforcing the ban on tobacco advertisements and promotions is a principal method for controlling tobacco (8). Tobacco marketing and promotions show a dose-response relationship and are the main reasons for starting or continuing smoking tobacco; point-of-sale displays play an important role for the tobacco industry. Children and adolescents are especially sensitive to advertisements and, as such, are targets for cigarette companies to expand brand share. Retail tobacco stand arrangements and displays are direct advertisements of tobacco products. Exposure to these advertisements promotes both tobacco products itself and the use of tobacco. It stimulates people to buy tobacco products, normalizes tobacco use and makes it difficult for those trying to quit smoking. Teenagers are especially affected by this. It has been proven in many studies that tobacco point-of-sale marketing encourages teenagers and children to start smoking $(3,9)$. Studies have shown that teenagers typically choose cigarette brands that are advertised constantly in the markets around their schools $(3,10)$. Similar studies performed in the USA showed that the more teenagers shopped, the more sellers advertised for cigarettes in the same market (3). Research done by Emri et al. (11) in Turkey showed that children aged between 7 and 13 were familiar with $80 \%$ and $90 \%$ of cigarette brand advertising and cigarette logos, respectively. By advertising to provide familiarity for particular cigarette brands, cigarette companies effectively increased the number of cigarettes smoked by adolescents $(3,12)$. Other evidence showing the importance of point-of-sale regulations for tobacco companies comes from their internal documents (3). It is accepted that locating sweet candy near tobacco products is also an effective technique to make children suppose that tobacco products are harmless and accessible like candy $(13,14)$. This research showed that tobacco products were generally located behind the checkout and were big enough to be easily seen and nearby products, like sweets, were targeted to children. Retail tobacco stores around schools have a special influence on students. According to a study done in Canada including 29 schools, each school had an average of 6.3 retailers, and cigarette use was significantly higher in the schools with more nearby retailers (15). Nearby tobacco retailers were accepted as a store within the six streets of the school in that study. According to research carried out by Chan et al. (16), the presence of tobacco retail outlets around schools increases the risk of children starting smoking. This study pointed out that the government should be careful when awarding licenses to points of sale around schools. A $1 \mathrm{~km}$ zone was accepted as being near a school in that research (16). It was found in another study that teenagers with cigarette retailers near their homes or schools were more likely to smoke (15). In that study, adolescents walking $400 \mathrm{~m}$ in five minutes was accepted as close-range. The only way to counteract the effects of advertisements is to remove tobacco point-of-sale displays from their field of vision (17). Legislation on point-of-sale displays is on the agenda in many countries, and also in Turkey, but retail outlets and point-of-sale displays 
are persistent. When we were carrying out the current study, adherence to new legislation was very low. ${ }^{2}$ However, as seen in Ireland, practices such as removing point-of-sale displays is highly effective when adherence is high (16).

According to the address-based population census results in 2008 , the population of the city center of Edirne was almost 153,000 (18). In this study, we found one tobacco retail outlet per 270 people. According to recent news published by a prominent financial paper in Turkey, the prevalence of cigarette points of sale is the highest in Edirne; there is one retail outlet per 245 people. This number is above average and is four times higher than the number in Istanbul. ${ }^{3}$ This situation is expected as Turkey is a country where smoking is very popular and, according to research done by us in the city center of Edirne in $2009,58 \%$ of adults $(68 \%$ of men and $54 \%$ of women) were currently smokers (19). The literature also shows a connection between retail tobacco outlet density and the prevalence of smoking (20-22). It has also been stated that generating a high density of tobacco retailers may be a marketing tactic of tobacco companies especially targeting the poor and minority races $(22,23)$. It would be beneficial not only to remove the point-of-sale displays from the field of vision, but also to categorize them according to population density and zones. Mapping techniques would also be beneficial for these measures.

The tobacco market in Turkey was liberalized after the 1980 s and totally privatized in 2008 . National and local state monopoly offices easily organized and controlled the retail tobacco environment; however, after the 2000s, the retail tobacco market was deregulated and liberated (the state offices were closed and retailer licensing was given to the City Chamber of Commerce and Industry). With the advertisement bans of Turkish Tobacco Control Law in 1996, the point-of-sale marketing gained importance and, in the absence of governmental supervision, retail tobacco outlets with displays appeared at almost every type of commercial location, including restaurants, charcuteries and even in stationeries. Before deregulation of the retail environment, tobacco products could not be sold within $100 \mathrm{~m}$ of schools, sport and education facilities. With the current situation, we speculated that Turkish governments halted the regulation of the tobacco marketing industry because of some hidden treaties with tobacco companies in the national tobacco monopoly privatization process, as mentioned in the report prepared for the International Union Against Tuberculosis and Lung Disease (24). This study clearly indicates that the Turkish government does not control the cigarette market sufficiently.

The major limitation of this study is that we did not determine the effects of cigarette smuggling. As a frontier city of Turkey, we found that $42 \%$ of students studying in secondary schools or high schools were able to buy smuggled cigarettes in 2002 (25). Although it is thought that the proportion of smuggled cigarettes is on the decline, the exact rate is unknown. This is one of the main reasons for the increasing prevalence of cigarette use especially among adolescents despite many legal precautions in Turkey. Although the smuggled cigarette market does not provide visual advertisement, it has the potential to affect the results of this research in terms of cigarette accessibility.
According to the existing legislation, the sales of tobacco in education, health, culture and sport facilities are banned; however, we think licenses should be abolished in unrelated stores like restaurants, cafes, stores with dried nuts and fruits and charcuteries, etc.

\section{Conclusion}

We concluded that one of the reasons for the increasing prevalence of cigarette use, especially among adolescents in Turkey, is deregulation of the retail tobacco marketing industry as a result of the privatization process of the national tobacco monopoly. All point-of-sale displays must be removed and retail stores must be licensed according to density and their proximity to schools, sport and health facilities. Using mapping techniques can be useful in terms of controlling the retail marketing environment.

Acknowledgements: The authors thank the students of the Trakya University Faculty of Education.

\section{Conflict of Interest}

No conflict of interest was declared by the authors.

\section{References}

1. Sağlık Bakanlığı Temel Sağlık Hizmetleri Genel Müdürlüğü. Küresel Yetişkin Tütün Araştırması Türkiye Raporu. 2010. Ankara, Sağlık Bakanlığı.

2. Harper T. Why the tobacco industry fears point of sale display bans. Tob Control 2006;15:270-1. [CrossRef]

3. Paynter J, Edwards R. The impact of tobacco promotion at the point of sale: a systematic review. Nicotine Tob Res 2009;11: 25-35. [CrossRef]

4. Henriksen L, Schleicher NC, Feighery EC, Fortmann SP. A longitudinal study of exposure to retail cigarette advertising and smoking initiation. Pediatrics 2010;126:232-8. [CrossRef]

5. TAPDK. Tütün mamulleri ve alkollü içkilerin satışına ve sunumuna ilişkin usul ve esaslar hakkında yönetmelik, Resmi Gazete, 2011;27808. http://www.resmigazete.gov.tr/eskiler/2011/01/20110107-2.htm (accessed 4 Oct 2011).

6. Fisher RP, Myers BA. Free and simple GIS as appropriate for health mapping in a low resource setting: a case study in eastern Indonesia. Int J Health Geogr 2011;10:15. [CrossRef]

7. Kaiser R, Spiegel PB, Henderson AK, Gerber ML. The application of geographic information systems and global positioning systems in humanitarian emergencies: lessons learned, programme implications and future research. Disasters 2003;27:127-40. [CrossRef]

8. World Health Organization. WHO Report on the Global Tobacco Epidemic, 2008: The MPOWER package. Geneva: World Health Organization; 2008.

9. Paynter J, Edwards R, Schluter PJ, McDuff I. Point of sale tobacco displays and smoking among 14-15 year olds in New Zealand: a cross-sectional study. Tob Control 2009;18:268-74. [CrossRef]

10. Wakefield MA, Ruel EE, Chaloupka FJ, Slater SJ, Kaufman NJ. Association of point-of-purchase tobacco advertising and promotions with choice of usual brand among teenage smokers. J Health Commun 2002;7:113-21. [CrossRef]

11. Emri S, Bagci T, Karakoca Y, Baris E. Recognition of cigarette brand names and logos by primary schoolchildren in Ankara, Turkey. Tob Control 1998;7:386-92. [CrossRef]

${ }^{2}$ Kesler M. Sigaralar hala vitrinde. Milliyet [National Newspaper], 8 Aug 2011

${ }^{3}$ Ersoy M. 20 bin esnaf alkol ve sigarayı bıraktı. Habertürk [National Newspaper], 2011 May 7. 
12. Pierce JP, Choi WS, Gilpin EA, Farkas AJ, Berry CC. Tobacco industry promotion of cigarettes and adolescent smoking. JAMA 1998;279:511-5. [CrossRef]

13. Pollay RW. More than meets the eye: on the importance of retail cigarette merchandising. Tob Control 2007;16:270-4. [CrossRef]

14. Barnoya J, Mejia R, Szeinman D, Kummerfeldt CE. Tobacco point-of-sale advertising in Guatemala City, Guatemala and Buenos Aires, Argentina. Tob Control 2010;19:338-41. [CrossRef]

15. Leatherdale ST, Strath JM. Tobacco retailer density surrounding schools and cigarette access behaviors among underage smoking students. Ann Behav Med 2007;33:105-11. [CrossRef]

16. Chan WC, Leatherdale ST. Tobacco retailer density surrounding schools and youth smoking behaviour: a multi-level analysis. Tob Induc Dis 2011;9:9. [CrossRef]

17. McNeill A, Lewis S, Quinn C, Mulcahy M, Clancy L, Hastings G, et al. Evaluation of the removal of point-of-sale tobacco displays in Ireland. Tob Control 2011;20:137-43. [CrossRef]

18. T. C. Edirne Valiliği. Türkiye İstatistik Kurumu Edirne Bölge Müdürlügü. Adrese dayalı nüfus kayıt sistemi 2008 Edirne Nüfus Sayımı sonuçları. http://www.edirne.gov.tr/default_ B0.aspx?content=217 (accessed 21 Aug 2011).

19. Karlıkaya C, Deveci S, Ekuklu G. Edirne'de sigara içme ve bırakma oranları. Fırat Üniversitesi Sağlık Bilimleri Tıp Dergisi 2009;23:25-9.
20. Chuang YC, Cubbin C, Ahn D, Winkleby MA. Effects of neighbourhood socioeconomic status and convenience store concentration on individual level smoking. J Epidemiol Community Health 2005;59:568-73. [CrossRef]

21. Novak SP, Reardon SF, Raudenbush SW, Buka SL. Retail tobacco outlet density and youth cigarette smoking: a propensity-modeling approach. Am J Public Health 2006;96:670-6. [CrossRef]

22. Peterson NA, Lowe JB, Reid RJ. Tobacco outlet density, cigarette smoking prevalence, and demographics at the county level of analysis. Subst Use Misuse 2005;40:1627-35. [CrossRef]

23. Fakunle D, Morton CM, Peterson NA. The importance of income in the link between tobacco outlet density and demographics at the tract level of analysis in New Jersey. J Ethn Subst Abuse 2010;9:249-59. [CrossRef]

24. Yürekli A, Önder Z, Elibol M, Erk N, Cabuk A, Fisunoglu M, et al. The economics of tobacco and tobacco taxation in Turkey. Paris: International union against tuberculosis and lung disease; 2010. http://www.tobaccofreeunion.org/content/en/217/ (accessed 5 Oct 2011).

25. Karlıkaya C. Edirne'de orta öğretim öğrencilerinde sigara içme prevalansı. Toraks Dergisi 2002;3:6-12. 